\title{
Competency-Based Curriculum Development
}

Ruth A. Wittmann-Price

"Life is a curriculum unique to every student."

-Joyce Rachelle

\section{OBJECTIVES}

- Discuss the development of competency-based education (CBE) curricula.

- Compare CBE to traditional curriculum models.

- Identify leadership attributes needed to develop or revise curricula.

\section{INTRODUCTION}

Competency-based education (CBE) is becoming the new curriculum model in healthcare for several reasons:

- Need for greater practitioner accountability

- Increased social expectations for quality care 
- Need for educational systems that can readily adapt to change (Ferguson et al., 2017).

This chapter will delve into the specifics of revising or developing a nursing curriculum using a CBE model. Curriculum revision or development must consider many variables, including the educational mission, the competencies identified as needed, the framework, and the constraints encountered in traditional educational systems.

\section{STEPS IN REVISING OR DEVELOPING A CBE NURSING CURRICULUM}

Revising or developing a curriculum is a rewarding process that takes time, teamwork, thought processes, flexibility, and an openness to change and new ideas. Often, nurse educators undertaking this endeavor have themselves been educated in a traditional, content-driven paradigm, which effects the process (Ferguson et al., 2017).

\section{Requirements for Curriculum Development}

- Culture change and buy-in from constituents

- Stakeholder input is necessary because "in today's educational climate, the value of education is measured against job marketability" (Boland, 2017, p. 1).

- A strong, knowledgeable leader to explain the benefits of change to faculty and articulate the vision of the final product.

- Resources like time, as faculty need time to be involved in a curriculum change or development process.

- An active and extensive communication so all faculty are informed as changes are voted on and take place.

Even one seemingly small curriculum change affects many variables such as:

- Course credits

- Faculty oversight

- Allocation of resources 
- Teaching responsibilities

- Graduation requirements

\section{Step 1: Revisit the Education Organization's and Department of Nursing's Mission}

Collectively, the faculty group should be able to articulate how the proposed curriculum model fits within the mission of the educational organization and the nursing program. Table 2.1. demonstrates a side by side congruency table.

\section{Step 2: Identify Program Outcomes (Goals and Objectives)}

The nursing program's outcomes are integrated with the competencies needed for graduates. Nursing faculty, when revising or developing a curriculum, need to establish and agree on the competencies needed for real-world practice by

Table 2.1

Mission and Curriculum Model Congruency Table

\begin{tabular}{|c|c|c|}
\hline $\begin{array}{l}\text { Organizational } \\
\text { Mission Elements }\end{array}$ & $\begin{array}{l}\text { Program Mission } \\
\text { Elements }\end{array}$ & $\begin{array}{l}\text { Elements of a CBE } \\
\text { Curriculum Model }\end{array}$ \\
\hline $\begin{array}{l}\text { University XX } \\
\text { endeavors to } \\
\text { educate students } \\
\text { from the region } \\
\text { (nationally, } \\
\text { internationally). }\end{array}$ & $\begin{array}{l}\text { The Department of } \\
\text { Nursing provides } \\
\text { excellent education } \\
\text { to students from the } \\
\text { region (nationally, } \\
\text { internationally). }\end{array}$ & $\begin{array}{l}\text { CBE provides an } \\
\text { efficient, effective } \\
\text { educational model. }\end{array}$ \\
\hline $\begin{array}{l}\text { University } \\
\text { XX promotes } \\
\text { innovative } \\
\text { learning based on } \\
\text { current evidence } \\
\text { to a diverse } \\
\text { population of } \\
\text { students in a real- } \\
\text { world setting. }\end{array}$ & $\begin{array}{l}\text { The Department of } \\
\text { Nursing strives to } \\
\text { educate competent, } \\
\text { caring professionals } \\
\text { from diverse } \\
\text { backgrounds who } \\
\text { can provide care } \\
\text { in today's complex } \\
\text { healthcare setting. }\end{array}$ & $\begin{array}{l}\text { CBE builds the } \\
\text { curriculum around } \\
\text { competencies that } \\
\text { include not only } \\
\text { skills, but also } \\
\text { cognition and } \\
\text { attitude. It is done on } \\
\text { an individual student } \\
\text { level to encompass } \\
\text { diversity. }\end{array}$ \\
\hline
\end{tabular}


graduates. Variables that need to be considered when identifying the competencies graduates should achieve include:

- Licensure test plans

- Certification test plans

- National nursing organization standards

- Accreditation standards and criteria

- State boards of nursing regulations

- Community, practice partners, and stakeholders' input

- Students who are part of the program's stakeholders (Storrar et al., 2019).

The curriculum is revised or developed in a top-down fashion. First, the competency is identified as a knowledge, skill, or attitude the students should possess at the end of the program. Then, the faculty need to identify how that will be accomplished. In other words, competencies are determined as the endpoint or outcome of the curriculum and the process is considered as a means to meet the outcome (Anema \& McCoy, 2010). Questions needed to be answered may include:

- At what level should this competency be introduced?

- How will the attainment of this competency be assessed?

\subsection{Example Vignette}

One standard integrated throughout nursing regulatory and accrediting agencies is evidence-based practice (EBP). At the end of the program, you may expect a baccalaureate nursing student to be able to implement an EBP project and evaluate the project's effectiveness. To reach this competency, the student will have to reach competencies all along the learning process, such as evaluating research literature, developing a researchable question, identifying the data needed to be collected, and analyzing data. 
- What content does this competency logically fit with?

- Who is the best facilitator of this competency?

- What is the plan if the benchmark for this competency is not reached by a student?

\section{CURRICULUM FRAMEWORK}

Curriculum frameworks organize how students learn cognitive content, psychomotor skills, and affective attributes (or knowledge, skills, and attitude) that are the desired educational outcome of a program (Boland, 2017). Nursing education can use many different types of curriculum organizational schemes, but all frameworks can be congruent with CBE. As the curriculum foundation, competencies can support many different methods of organizing topics.

\section{Traditional and Non-Traditional Frameworks}

- Single theory frameworks: one theorist's concepts and assumptions frame nursing content

- Eclectic frameworks: more than one theory organizes the nursing content, for example, Maslow and a nursing theorist

- Non-traditional frameworks: a variety of ideas are used, for example:

- KSVME Framework-this framework is built around five cornerstones (nursing knowledge, skills, values, meanings, and experience)

- Healing Web Framework-transformative model around practice that has components of Newman's and Watson's model

- The Emancipatory Framework-promotes learning through discovery, dialogue, and reflection

- Quality and Safety Education in Nursing (QSEN) framework, which was developed to promote quality and safety (Boland, 2017). 
In addition to the nursing framework, curricula are organized into a schema that can outline course development. Some of the organizations in nursing are:

- Population-based (courses in adult health, psychiatric mental health, maternal-child health)

- Body systems-based (cardiac, respiratory, etc.)

- Concept-based (advocacy, caring, oxygenation, circulation, etc.)

Once nursing faculty decide on a curriculum framework and organization, the competencies can be infused into the system and appropriately placed in courses. In a pure system of $\mathrm{CBE}$, the competencies do not have to be linked to courses.

\section{BOX 2.1 EVIDENCE-BASED TEACHING PRACTICE}

The University of Michigan Master of Health Professions Education degree is an example of a fully organized competency-based education. The competencies identified as essential replaced courses, the time frame for competency mastery is flexible and individualized, and the faculty are mentors (University of Michigan, 2019).

\section{THE COPA MODEL}

Since 1979, Lenburg has been developing the COPA (Competency Outcomes Performance Assessment) model. The COPA model is composed of four pillars (Figure 2.1).

Lenburg et al. (2009) describe the first pillar as the core practice competencies that include all eight universal competencies (See Table 2.2) integrated in every course and guiding the development of outcome statements.

The essential competencies encompass the major standards of practice for nursing similar to other nursing organizations (Lenburg, 1999). The faculty revising or developing a 
Figure 2.1 The four pillars of the COPA model.

\section{Table 2.2}

\section{Eight Universal Core Competencies}

\begin{tabular}{|c|c|}
\hline Competency & Examples \\
\hline $\begin{array}{l}\text { Assessment and } \\
\text { interventions skills }\end{array}$ & $\begin{array}{l}\text { Safety and protection as well as monitoring } \\
\text { and treating patients and families }\end{array}$ \\
\hline Communication skills & $\begin{array}{l}\text { Oral, writing, and computing skills needed } \\
\text { to communicate with patients and families, } \\
\text { document care, and search for best practice } \\
\text { guidelines and evidence }\end{array}$ \\
\hline Critical thinking skills & $\begin{array}{l}\text { Evaluation of variables and clinical } \\
\text { decision-making }\end{array}$ \\
\hline $\begin{array}{l}\text { Human caring and } \\
\text { relationship skills }\end{array}$ & $\begin{array}{l}\text { Legal and ethical considerations as well as } \\
\text { cultural humility and patient and family } \\
\text { advocacy }\end{array}$ \\
\hline Management skills & $\begin{array}{l}\text { Prioritization, delegation, and } \\
\text { accountability }\end{array}$ \\
\hline Leadership skills & Planning, assertiveness, and creativity \\
\hline Teaching skills & Health promotion and restoration \\
\hline $\begin{array}{l}\text { Knowledge } \\
\text { integration skills }\end{array}$ & $\begin{array}{l}\text { Interdisciplinary understanding and } \\
\text { interprofessional collaboration }\end{array}$ \\
\hline
\end{tabular}

Source: Adapted from Lenburg, C. B. (1999). The framework, concepts, and methods of the competency outcomes and performance assessment (COPA) model. Online Journal of Issues in Nursing, 4(3). http://ojin.nursingworld.org/ MainMenuCategories/ANAMarketplace/ANAPeriodicals/ 
CBE curriculum should look at many different organizational standards and choose one set or develop their own, making sure key competencies every nursing graduate should know for contemporary nursing care are accounted for.

\section{DEVELOPING COURSES TO OPERATIONALIZE CBE}

- Course syllabi will outline the competencies for each course and the student learning outcomes or outcome statements. Together, these will map the road more specifically on how to achieve the broader program outcomes or competencies. The learning outcome determines the selection of learning resources.

- Competency writing uses different terms from Bloom et al. (1956) taxonomy compared with student learning outcomes. Competencies are practice-driven, whereas student learning outcomes are content-driven (Anema \& McCoy, 2010; Table 2.3).

- The learning resources for each course are aligned with the assessments that evaluate the competencies (Figure 2.2; Johnstone \& Soares, 2014).

Table 2.3

Differences in Verbs Used for Competencies and Student Learning Outcomes

Competency Statement

Demonstrate a complete physical assessment on an adult.

Integrate two evidence-based best practices when caring for a new mom.

Implement best practice for an oncology patient actively receiving chemotherapy.

\section{Student Learning Outcomes}

Describe how to perform a physical assessment of an adult patient.

Discuss treatment options with a new mom.

List nursing interventions used to reduce the side effects of chemotherapy for an adult. 
Remediation

if needed

Aligned assessments

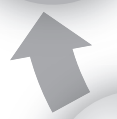

Course

student

learning

outcomes

Learning

resources

Figure 2.2 Course alignment.

\section{BOX 2.2 EVIDENCE-BASED TEACHING PRACTICE}

Due to a lack of orientation processes for new nurse practitioners (NPs), Kopf et al. (2018) developed a competency-based curriculum to assist NP students' transition into practice. Transitioning into practice from academia is stressful, and the authors developed a competency list based on NP practice in the intensive care unit. Competencies were placed in categories that aligned with NP pre-certification education. Competencies were listed under each category and the lists were sent to experts for validation. National experts rated each competency on a Likert scale and nine competency topics were retained.

Once the faculty decides on the program competencies and the framework, the curriculum revision or development can turn to forming syllabi. Course syllabi should reflect CBE by 
conveying to students the outcome expectations that drive each course and, ultimately, the program competencies. The student learning outcomes should be listed on the syllabi and assist the students in accomplishing the competencies. The students facilitate their learning in all three domains (psychomotor or skills, cognitive or knowledge, and affective or attitude), with each student accomplishing the competencies at a different pace. Benchmarks are set up along the way with no discrete timeline.

\section{Fast Facts}

"Competence that is acquired through participation in the program may take place quickly or more slowly, depending on the learner's prior competence level, prior professional activities, motivation, and learning opportunities" (Gruppen et al., 2016).

Some authors describe the benchmarks as "milestones" or concrete behavioral descriptions that are developmental steps to achieve the competency. Competencies encompass multiple domains, which cannot be splintered for assessment in the end (Touchie \& Cate, 2016).

Robinson (2018) provides examples of well-defined competencies for the end of an RN-BSN curriculum, which include:

\subsection{Example Vignette}

If a competency is starting an intravenous infusion on an adult, there is an understanding that communication, professionalism, nursing knowledge, and clinical reasoning skills are integrated into the physical task. The entire patient encounter is assessed as a whole because assessing any one part separately is meaningless when facilitating competency achievement (Touchie \& Cate, 2016). 
- Make clinical decisions based on the best available evidence

- Prioritize actions based on patient safety needs

Robinson's competencies can then be broken down into course competencies or milestones to be achieved within the curriculum framework. Table 2.4 demonstrates a competency's alignment with a course.

Table 2.4

\section{Alignment of a Competency with Course Student Learning Outcomes}

\begin{tabular}{|c|c|}
\hline $\begin{array}{l}\text { Competency } \\
\text { to be met by } \\
\text { the End of the } \\
\text { Program. }\end{array}$ & $\begin{array}{l}\text { Make clinical decisions based on the best available } \\
\text { evidence. }\end{array}$ \\
\hline
\end{tabular}

\begin{tabular}{|c|c|c|}
\hline Course & $\begin{array}{l}\text { Student } \\
\text { Learning } \\
\text { Outcomes in } \\
\text { Courses }\end{array}$ & Assessment \\
\hline $\begin{array}{l}\text { Contemporary } \\
\text { Nursing } \\
\text { Course }\end{array}$ & $\begin{array}{l}\text { Discuss the } \\
\text { importance } \\
\text { of evidence- } \\
\text { based practice } \\
\text { in relation to } \\
\text { the American } \\
\text { healthcare } \\
\text { system. }\end{array}$ & $\begin{array}{l}\text { Written paper } \\
\text { about process } \\
\text { improvement } \\
\text { to decrease } \\
\text { healthcare } \\
\text { errors. }\end{array}$ \\
\hline $\begin{array}{l}\text { Nursing } \\
\text { Research } \\
\text { Course }\end{array}$ & $\begin{array}{l}\text { Categorize } \\
\text { evidence } \\
\text { according } \\
\text { to the Iowa } \\
\text { model. }\end{array}$ & $\begin{array}{l}\text { Submit a table } \\
\text { of at least five } \\
\text { peer-reviewed } \\
\text { articles on a } \\
\text { clinical topic. }\end{array}$ \\
\hline $\begin{array}{l}\text { Nursing } \\
\text { Leadership } \\
\text { Course }\end{array}$ & $\begin{array}{l}\text { Demonstrate } \\
\text { the evidence } \\
\text { used to make } \\
\text { a clinical } \\
\text { decision. }\end{array}$ & $\begin{array}{l}\text { Explain to } \\
\text { clinical faculty } \\
\text { why a nursing } \\
\text { treatment was } \\
\text { chosen. }\end{array}$ \\
\hline
\end{tabular}


Identified course competency Beginning Level (Novice)

Supported by:

Course

competencies

Aligned assessment

strategies

Figure 2.3 CBE course linkages.

\section{Fast Facts}

Entrustable Professional Activities (EPAs) is a term used in medical schools to map competencies to assessable outcomes or attributes that one would want to see in a healthcare professional.

In $\mathrm{CBE}$, the competency, the content being learned, and the assessment all have a well-defined relationship (Shinners \& Graebe, 2019). The course syllabus becomes a concept map for faculty that is leveled within the CBE curriculum. Figure 2.3 connects the pieces making up a CBE course using Benner's (1984) Novice to Expert Theory.

\section{Fast Facts}

Traditional course development may appear similar to CBE course development, but the difference lies in the outcome. In traditionally graded courses, the students can pass or fail a course but not achieve all the competencies at a satisfactory level. This may occur because the final grade is an average 
of all course assessments. In CBE, each critical competency needs to be passed at a safe level for the student to move along in the program of study (Anema \& McCoy, 2010).

\section{BOX 2.3 EVIDENCE-BASED TEACHING PRACTICE}

One method to view competency building has been proposed by Juceviciene and Lepaite (2005), as outlined in Anema and McCoy.

\begin{tabular}{|c|c|c|}
\hline & Type of Competency & Purpose \\
\hline Level 1 & $\begin{array}{l}\text { Behavior } \\
\text { competencies }\end{array}$ & $\begin{array}{l}\text { To achieve the performance } \\
\text { needed in the workplace }\end{array}$ \\
\hline Level 2 & $\begin{array}{l}\text { Added } \\
\text { competencies }\end{array}$ & $\begin{array}{l}\text { To improve the work } \\
\text { environment using the } \\
\text { behavioral competencies with } \\
\text { additional knowledge }\end{array}$ \\
\hline Level 3 & $\begin{array}{l}\text { Integrated } \\
\text { competencies }\end{array}$ & $\begin{array}{l}\text { To make positive workplace } \\
\text { changes using behavioral and } \\
\text { added competencies }\end{array}$ \\
\hline Level 4 & $\begin{array}{l}\text { Holistic } \\
\text { competencies }\end{array}$ & $\begin{array}{l}\text { To transfer knowledge to new } \\
\text { situations }\end{array}$ \\
\hline
\end{tabular}

Source: Adapted from Anema, M. G., \& McCoy, J. (2010). Competencybased nursing education: A guide to achieving outstanding learning outcomes. Springer Publishing Company (p. 5)

The flexibility of time is one of the most difficult CBE aspects to integrate. Higher education functions on a welldeveloped time frame, and removing that parameter means revising many academic offices such as Registrar, Financial Aid, Graduation, and Student Services (Gruppen et al., 2016). To "fit in" to an academic schema, many CBE models use the end of the semester as the "outcome point" but leave achievement of milestones flexible within the semester. 


\section{ALIGNING EDUCATIONAL ACTIVITIES}

Once the syllabi integrate the appropriate leveled competencies that will lead to program competencies or outcomes, faculty have to decide what teaching/learning activities or teaching strategies are relevant for accomplishment of these competencies. In many cases, this means different activities than in traditional educational models because each student needs to practice and achieve a competency in their own time frame. Also, multiple teaching/learning strategies provide flexibility for different types of learners. Some teaching strategies that lend themselves to active learning include:

- Cooperative learning

- Discussions

- Group projects

- Peer tutoring

- Learning cells

- Problem-based learning

- Games

- Simulations

- Portfolios

- Presentations

- Journaling

\section{Fast Facts}

"In $\mathrm{CBE}$, the clinical setting becomes an intentional, structured environment for context-specific learning, skill development, and assessment" (Mace \& Bacon, 2018, p. 303).

\section{BOX 2.1 EVIDENCE-BASED TEACHING PRACTICE}

Mace and Bacon (2018) surveyed athletic trainers ( $n=$ 163) to find out how much they know about CBE and 
how confident they were in using it as an educational modality. Knowledge and confidence scores were both low, demonstrating that although the term CBE is used in the discipline, faculty needed further information.

\section{LEADERSHIP FOR CURRICULUM REVISION OR DEVELOPMENT}

Faculty are the main force propelling a curriculum revision or development, but the task also requires leadership to organize the process. Deciding on a curriculum leader is important, and the curriculum leader needs to understand the content and process of curriculum revision or development (Yoder-Wise, 2013). Curriculum leaders emerge in the following ways:

- Emergent leadership-The members of the group view the leader as someone who is knowledgeable and trustworthy; they recognize and accept the leader's influence to lead.

- Imposed or organizational leadership-The leader is appointed by someone outside the group. If the group members do not have confidence in the appointed leader's abilities, they may not perform to their highest potential (McHugh, 2017).

Five practices associated with exceptional leadership are as follows:

1. Challenging the process by searching for opportunities, experimenting, and taking risks

2. Inspiring a shared vision by envisioning the future and enlisting the support of others

3. Enabling others to act by fostering collaboration and strengthening others 
4. Modeling the way by setting an example and planning small successes

5. Encouraging the heart by recognizing contributions and celebrating accomplishments (Huber, 2000).

Leading curriculum revision or development is challenging because all faculty have invested time and energy into a current curriculum or one they know from previous educational experiences or employment (Venance et al., 2014).

\section{BOX 2.2 EVIDENCE-BASED TEACHING PRACTICE}

Venance et al. (2014) used a grounded theory approach to study the perception of faculty ( $n=16)$ on curriculum change and what influences faculty engagement. Interviews of faculty about curriculum change revealed three critical change barriers:

1. Tension between individual and institutional values

2. Tension between drivers of change and restrainers of change

3. Tension between perceived gains and perceived losses.

A large driver of change was faculty understanding their part in the change and knowing the rationale for change.

\section{SUMMARY}

Revising or developing a curriculum to include CBE takes knowledge, time, and reflection. A strong, visionary leader is needed, as well as faculty who understand the rationale for change and engage in the process. The change begins with reviewing the mission of the organization and educational 
unit and aligning the change with the needs of the stakeholders. A curriculum framework organizes content and competencies. Milestones are built in to ensure logical succession of competency achievement. Remediation processes are available to ensure success. Assessment and evaluation of competency achievement is completed along the way to ensure student success in reaching program outcomes.

\section{REFERENCES}

Anema, M. G., \& McCoy, J. (2010). Competency-based nursing education: A guide to achieving outstanding learning outcomes. Springer Publishing Company.

Benner, P. (1984). From novice to expert: Excellence and power in clinical nursing practice. Addison-Wesley.

Bloom, B. S., Engelhart, M. D., Furst, E. J., Hill, W. H., \& Krathwohl, D. R. (1956). Taxonomy of educational objectives: The classification of educational goals. Handbook I: Cognitive domain. David McKay Company.

Boland, D. L. (2017). Developing curriculum: Frameworks, outcomes, and competencies. Nurse Key. https://nursekey.com/developing -curriculum-frameworks-outcomes-and-competencies/

Ferguson, P. C., Caverzagie, K. J., Nousiainen, M. T., \& Snell, L. (2017). Changing the culture of medical training: An important step toward the implementation of competency-based medical education. Medical Teacher, 39(6), 599-602. http://dx.doi.org/10 .1080/0142159X.2017.1315079

Gruppen, L. D., Burkhardt, J. C., Fitzgerald, J. T., Funnell, M., Haftel, H. M., Lypson, M. L., Mullan, P. B., Santen, S. A., Sheets, K. J., Stalburg, C. M., \& Vasquez, J. A. (2016). Competency-based education: Programme design and challenges to implementation. Medical Education, 50, 532-539. http://dx.doi.org/10.1111/ medu. 12977

Huber, D. (2000). Leadership and nursing care management (2nd ed.). W. B. Saunders.

Johnstone, S. M., \& Soares, L. (2014). Principles for developing competency-based education programs. Change: The Magazine for Higher Learning, 46(2), 12-19. https://naspa.tandfonline.com/ doi/full/10.1080/00091383.2014.896705\#.XQEHlY97nIU 
Juceviciene, P., \& Lepaite, D. (2005). Competence as derived from activity: The problem of their level correspondence. Institute of Educational Studies, University of Technology.

Kopf, R. S., Watts, P. I., Meyer, E. S., \& Moss, J. A. (2018). A competency-based curriculum for critical care nurse practitioners' transition to practice. American Journal of Critical Care, 27(5), 398-406. http://dx.doi.org/10.4037/ajcc2018101

Lenburg, C. B. (1999). The framework, concepts, and methods of the competency outcomes and performance assessment (COPA) model. Online Journal of Issues in Nursing, 4(3). http://ojin .nursingworld.org/MainMenuCategories/ANAMarketplace/ ANAPeriodicals/

Lenburg, C. B., Klein, C., Abdur-Rahman, V., Spenser, T., \& Boyer, S. (2009). The COPA model: A comprehensive framework designed to promote quality care and competence for patient safety. Nursing Education Perspectives, 30(5), 312-317.

Mace, K. L., \& Bacon, C. E. W. (2018). Athletic training educators' knowledge and confidence about competency-based education. Journal of Athletic Training, 13(4), 302-308. https://doi .org/10.4085/1304302

McHugh, M. L. (2017). Curriculum design and evaluation of program outcomes. In R. Wittmann-Price, M. Godshall, \& L. Wilson (Eds.), Certified Nurse Educator (CNE) review manual. Springer Publishing Company.

Robinson, F. P. (2018). Competency-based education: An innovative option for nurses. American Nurse Today, 13(10), 38-40.

Shinners, J., \& Graebe, J. (2019). Continuing professional development: Utilizing competency-based education and the American Nurses Credentialing Center outcome-based continuing education model. Journal of Continuing Education in Nursing, 50(3), 100-102. http://dx.doi.org/10.3928/00220124-20190218-02

Storrar, N., Hope, D., \& Cameron, H. (2019). Student perspective on outcomes and process: Recommendations for implementing competency-based education. Medical Teacher, 41(2), 161-166. http://dx.doi.org/10.3928/00220124-20180517-02

Touchie, C., \& Cate, O. (2016). The promise, perils, problems and progress of competency-based medical education. Medical Education, 50, 93-100. http://dx.doi.org/10.1111/medu.12839

University of Michigan. (2019). Master of Health Professions Education. https://medicine.umich.edu/dept/lhs/education/master-health -professions-education 
Venance, S. L., LaDonna, K. A., \& Watling, C. J. (2014). Exploring frontline faculty perspectives after a curriculum change. Medical Education, 48(10), 998-1007. http://dx.doi.org/10.1111/ medu.12529

Yoder-Wise, P. S. (2013). Leading and managing in nursing (5th ed.). Elsevier. 